\title{
Root:shoot ratios and belowground biomass distribution for Pacific Northwest dryland crops
}

\author{
J.D. Williams, D.K. McCool, C.L. Reardon, C.L. Douglas, Jr., S.L. Albrecht, and R.W. Rickman
}

\begin{abstract}
Roots, cereal crowns, and stems growing beneath the soil surface provide important resistance to soil erosion. Understanding the amount and distribution of this material in the soil profile could provide insight into resistance to soil erosion by water and improve the performance of soil erosion models, such as the revised universal soil loss equation (RUSLE) and the water erosion prediction project (WEPP). Erosion models use built-in or external crop growth models to populate crop yield and live aboveground and associated belowground biomass databases. We examined two data sets from the dryland small grain production region in the Pacific Northwest of the United States to determine root:shoot ratios, the vertical distribution of root and attached belowground biomass, and incorporated residue from previously grown crops. Data were collected in 1993, 1994, 1995, and 2000 from short-term no-till and conventional tillage experiments conducted near Pendleton, Oregon, and Pullman, Washington, and in 1999 and 2000 from long-term experiments representative of farming practices near Pendleton, Oregon. The crops sampled in the short-term data set included soft white winter and spring wheat (Triticum aestivum L.;WW and SW, respectively) spring peas (Pisum sativum L.; SP), and winter canola (Brassica napus L.; WC). Crops sampled in the long-term study included WW, SW, and SP. Data were collected at harvest in both data sets and during three phenologic stages in each of the crops in the short-term data set. Soil samples were collected to a depth of $60 \mathrm{~cm}(23.6 \mathrm{in})$ in the short-term and $30 \mathrm{~cm}(11.9 \mathrm{in})$ in the long-term experiments. In both sets of measurements, we found greater than $70 \%$ of root mass is in the top $10 \mathrm{~cm}$ (3.9 in) of the soil profile with the exception of SP, which had $70 \%$ of root mass in the top $15 \mathrm{~cm}$ (5.9 in) of the soil profile. WC produced significantly more biomass near the soil surface than WW, SW, or SP. Root-to-shoot biomass ratios in mature wheat ranged from 0.13 to 0.17 in the top $30 \mathrm{~cm}(11.9$ in) of the soil profile, substantially lower than values suggested for use in WEPP (0.25). In the long-term experiments, soil of the conventionally tilled continuous winter wheat (CWW) plots contained significantly greater biomass than soil of conventionally tilled winter wheat/fallow (CR) and no-till winter wheat/fallow (NT) treatments. There was no significant difference between CWW and conventionally tilled winter wheat/spring pea (WP); however, CWW returned more residue to the soil than WP because SP produced less residue and these residues were incorporated with a field cultivator rather than a moldboard plow. More accurate representation of root development, particularly in winter crops, could improve RUSLE and WEPP performance in the Pacific Northwest where winter conditions have proven difficult to model.
\end{abstract}

Key words: canola — incorporated residue - peas — root mass - root-shoot ratio-wheat

\begin{abstract}
A Mediterranean climate of wet, cool winters and dry, hot summers has proven to be optimal conditions for dryland small grain production on the Columbia Plateau in the Pacific Northwest, United States (PNW). Annual precipitation constrains cropping practices across the region, with crops
\end{abstract}

grown biennially in the drier areas of central Washington and northern Oregon and annually in the wetter areas in southeastern Washington and adjacent Idaho. This biennial production system is typically conducted with winter wheat (Triticum aestivum L.) (WW) planted in the fall and harvested the follow- ing July through August, followed by 12 or more months of fallow. Historically, farming practices coupled with winter weather events led to excessive soil erosion in this region. Seedbed preparation and weed control created thoroughly tilled, structureless, bare soil conditions that frequently combined with fall rains and cold temperatures to freeze the soil into an impermeable mass. Winter warm periods can thaw the surface soil, leaving a weak thawed layer over the impermeable subsurface layer. Subsequent rainfall or snowmelt can lead to substantial rill erosion ( $\mathrm{McCool}$ et al. 1982). Despite the low intensity rainfall predominant in this region, mean soil loss between 1939 and 1977 in the Palouse River subbasin was estimated at $20.6 \mathrm{Mg} \mathrm{ha}^{-1} \mathrm{y}^{-1}$ (9.2 $\mathrm{t} \mathrm{ac}^{-1} \mathrm{yr}^{-1}$ ) (Ebbert and Roe 1998; USDA 1978). At a site near Dufur, Oregon, about $161 \mathrm{~km}(100 \mathrm{mi})$ west of Pendleton, Oregon, Zuzel et al. (1982) reported soil loss as great as $31 \mathrm{Mg} \mathrm{ha}^{-1}\left(13.8 \mathrm{tn} \mathrm{ac} \mathrm{ac}^{-1}\right)$ in a five-week winter period from fields in WW following summer fallow.

Moldboard plowing and multiple secondary tillage practices destroy soil aggregates mechanically through the disruption of root systems and filamentous fungi which entwine and stabilize macroaggregates (Jastrow et al. 2007; Miller and Jastrow 2000). Aggressive inversion tillage practices, by burying crop residue, dead roots, and cereal crowns, leave soil bare and vulnerable to both wind and water erosion (Williams et al. 2000) and rill development (McCool et al. 1987). Renard and Simanton (1990) considered erosion control primarily the result of residue and roots in the top $10 \mathrm{~cm}$ (3.9 in) of soil. Indeed, field studies have shown erosion of Walla Walla and Palouse silt loam soils is inversely related to the root and residue mass returned to the soil as a result of the tillage practices and crop rotation (Williams 2008; Williams et al. 2009). Similarly, if small grain residues are removed from the field after harvest, multiple tillage operations before

John D. Williams is a research hydrologist with the USDA Agricultural Research Service in Pendleton, Oregon. Don K. McCool is a retired agricultural engineer and collaborator with the USDA Agricultural Research Service in Pullman, Washington. Catherine L. Reardon is a microbiologist with the USDA Agricultural Research Service in Pendleton, Oregon. Clyde L. Douglas, Jr., Stephan L. Albrecht, and Ron W. Rickman are retired soil scientists, formerly with the USDA Agricultural Research Service, Pendleton, Oregon. 
seeding will dislodge shallow roots and cereal crowns and increase vulnerability to erosion (McCool et al. 2008). More recently, however, wide-spread adoption of conservation tillage practices and more benign weather patterns have resulted in a substantial reduction in soil loss rates ( $\mathrm{McCool}$ and Roe 2005; McCool et al. 2006).

The goal of conservation tillage is to leave more crop residue at the soil surface and the soil less disturbed than conventional tillage. Residue at the surface (especially plant stems) and belowground plant material (roots, cereal crowns, plant residues, and microbial components) contribute to the soil structure necessary to resist soil erosion by snowmelt runoff, raindrop impact, and concentrated flow. The shear strength provided by the physical binding and gluing (by root exudates) of soil particles into stable soil aggregates plays a substantial role in preventing erosion.

In erosion models used in decision support systems for conservation planning, it is important that crop components and management effects be properly represented. For example, if belowground to aboveground (root:shoot) biomass ratios are over- or underestimated, roots will not play their proper role in estimating soil erosion. This could be a critical shortcoming, especially in WW where root development during the fall is important for binding soil aggregates before the onset of winter storms and in the subsequent year if WW residues are removed after harvest. Furthermore, the accumulation of dead root biomass from year to year will not be correct, leading to an accumulation of errors in continuous, multiyear model runs. Unfortunately, little data are available on the actual amount and distribution of belowground plant parts in the PNW, or elsewhere in the United States.

Our objectives were to evaluate (1) root:shoot ratios and belowground live biomass distribution at specified development stages for selected crops in the PNW and (2) belowground biomass distribution in selected crops under different tillage systems in the PNW. To gain a robust view of root:shoot ratios and distribution of root mass and other live belowground plant components, we collected samples from 2- to 3-year short-term experiments; for distribution of live and dead root mass and incorporated residue, we collected data for short periods from established long-term
(14- to 71-year) experiments. This information should be useful in crop growth model and database validation for erosion models, such as versions of the revised universal soil loss equation (RUSLE) (Renard et al. 1997), RUSLE2 (USDA ARS 2008), and the water erosion prediction project (WEPP) (USDA ARS 1995), and aid in validating decomposition and carbon sequestration models.

\section{Materials and Methods}

Study Sites. Samples were collected from research sites at the USDA Columbia Plateau Conservation Research Center (USDA CPCRC) and the Oregon State University Columbia Basin Agricultural Research Center (OSU CBARC), $14 \mathrm{~km}$ (8.7 mi) northeast of Pendleton, Oregon, and at the Palouse Conservation Field Station, $3 \mathrm{~km}$ (1.9 mi) north of Pullman, Washington. Soil at Pendleton is a Walla Walla silt loam (coarse-silty, mixed, mesic Typic Haploxeroll) (Johnson and Makinson 1988); the soil at Pullman is a Palouse silt loam (fine-silty, mixed, mesic Pachic Ultic Haploxeroll) (Donaldson 1980). The Walla Walla series consists of deep, well-drained soil formed in loess on rolling uplands with $10 \%$ to $17 \%$ clay and less than $15 \%$ sand that is coarser than very fine sand (Johnson and Makinson 1988). The Palouse series consists of deep, well-drained, neutral soil with $20 \%$ to $35 \%$ clay and less than $15 \%$ sand that is coarser than very fine sand, formed in loess on rolling uplands (Donaldson 1980). Volcanic ash in the surface of both of these soils results in relatively low bulk density values from 1.1 to $1.3 \mathrm{Mg} \mathrm{m}^{-3}$ (Krynine 1937; Don Wysocki, personal communication, October 26, 2012).

The samples collected near Pendleton were within the intermediate precipitation zone (30 to $45 \mathrm{~cm}$ [11.8 to $17.7 \mathrm{in}]$ ) of the PNW at the boundary between annual and semiannual crop/fallow production. Cooler, wetter (54 cm [21.3 in]) annual cropping conditions are represented by the site near Pullman. Precipitation and air temperatures for Pendleton and Pullman for the crop years of the study are presented in figure 1.

Generally, the belowground portions of plant growth have been combined into the catchall category of roots. For wheat plants and other cereal grains, we use the sequence of growth described by Karow et al. (1993) in order to differentiate between coleoptiles and seminal roots growing from the seed and crown development and the roots and shoots growing from the crown (figures $2 \mathrm{a}$ and $2 \mathrm{~b}$ ). According to this sequence, the coleoptile emerges from the wheat seed at germination, and the first true leaf grows from the coleoptile. The subcrown internode forms above the seed, and the crown develops above the subcrown internode. After the crown forms, the stems, leaves, tillers, and crown roots appear from the crown in a regular pattern, and the first true leaf disappears. Crown roots are the primary suppliers of water and nutrients to the plant (figure 2a). Depending on the depth below the soil surface at which the crown forms, part of the stem, leaves, and tillers may be beneath the soil surface. In this study, these are considered part of the crown and contribute to belowground biomass in the process of separating shoots from roots (figure $2 \mathrm{~b}$ ).

Generally, there is adequate spring seedbed moisture in the PNW to allow relatively shallow planting depths of 2 to $5 \mathrm{~cm}(0.8$ to 2 in). Similar seeding depths are used for fall seeding of small grains in the higher precipitation zone where ample fall rains are expected. In the low to intermediate precipitation zones, WW crops are planted into a seedbed following a year of fallow (also known as summer fallow). Planting depth is 5 to $8 \mathrm{~cm}$ ( 2 to 3.1 in) so seeds are placed into contact with soil with moisture adequate for germination. The coleoptile growth is limited to 8 to $10 \mathrm{~cm}$ (3.1 to $3.9 \mathrm{in}$ ), and if seeds are planted too deep, the coleoptile will not break the soil surface and the first true leaf will not emerge. The amount of material (stem, leaves, and tillers) between the base of the crown and soil surface will depend on a number of factors, but the length will depend on the depth at which the base of the crown forms. For this study, all live material (roots and crowns) beneath the soil surface are considered as belowground biomass, whereas shoot material consists of aboveground portions of the plant. Crown material (crown; subcrown internode; and belowground stems, leaves, and tillers) was separated from belowground biomass where phenologic stage is reported.

Identification of individual plants and plant parts was conducted using the protocol described by Douglas et al. (1990). The root growth patterns for the other crops in our study, spring pea (Pisum sativum L.; SP) and winter canola (Brassica napus L.; WC), are quite different from small grains; no crown is present. For SP, single plant stems emerge at 


\section{Figure 1}

(a) Precipitation and (b) air temperature values for crop years 1993, 1994, 1995, 1999, and 2000 with long-term records from Pendleton, Oregon, and Pullman, Washington. Confidence intervals (95\%) based on 79 years of record for Pendleton and 62 years at Pullman.

(a)

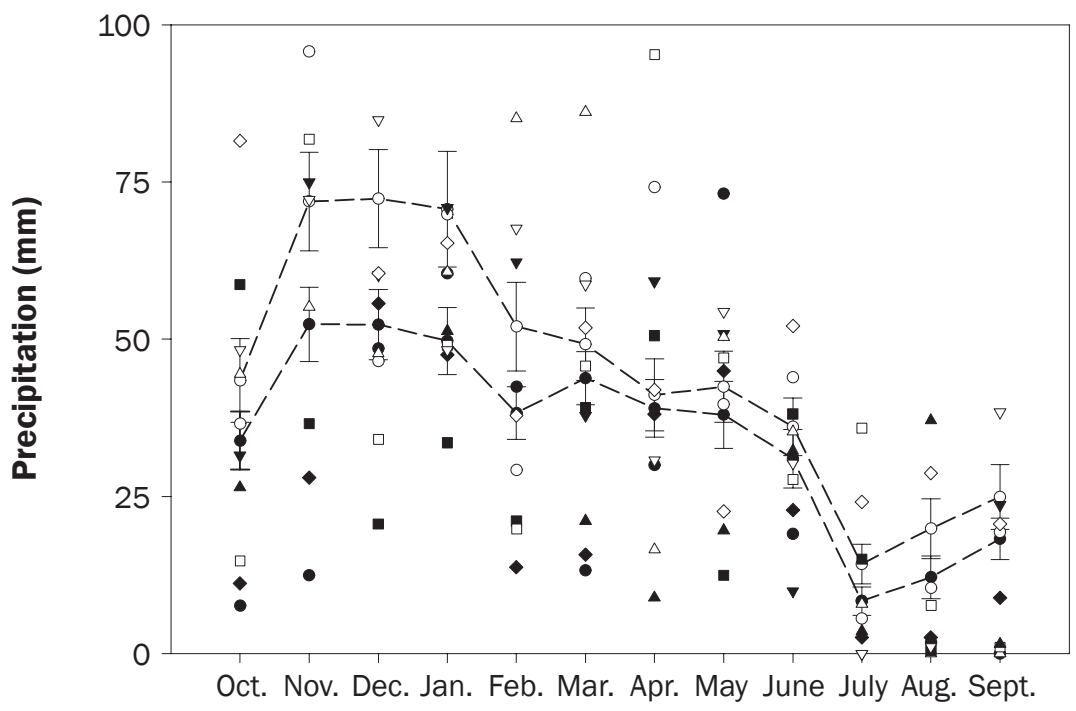

(b)

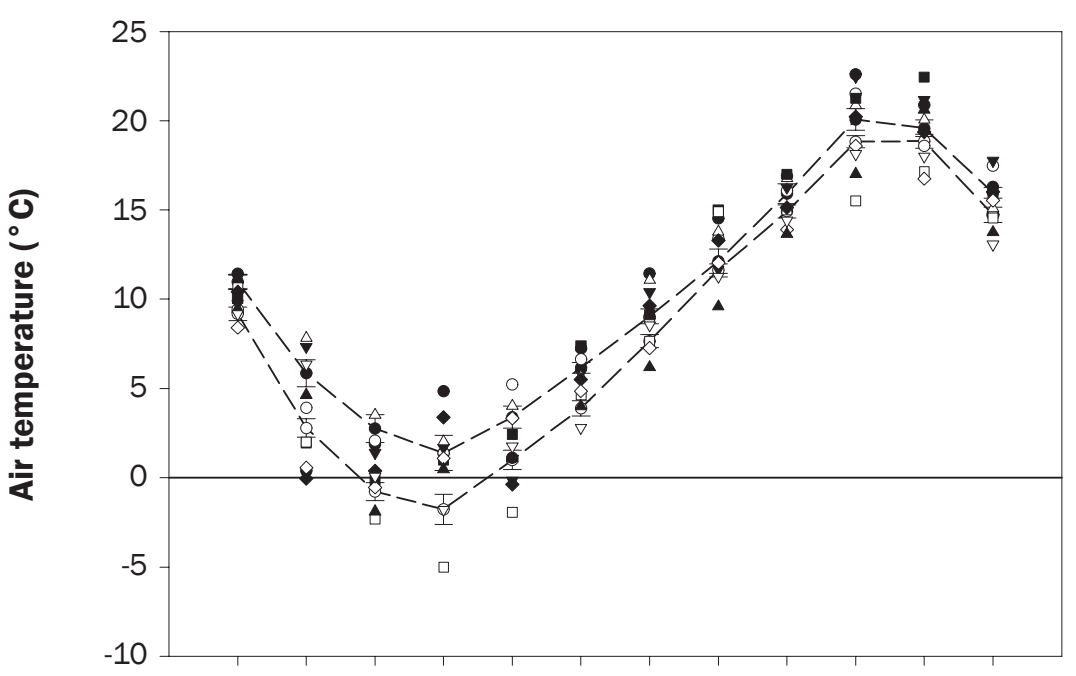

Oct. Nov. Dec. Jan. Feb. Mar. Apr. May June July Aug. Sept.

\section{Month}

\section{Legend}

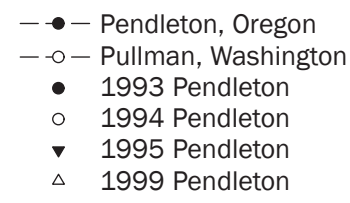

- 2000 Pendleton

- 1993 Pullman

- 1994 Pullman

$\diamond 1995$ Pullman

- 1999 Pullman

$\nabla 2000$ Pullman or quite near the soil surface. The WC plant grows from a rosette.

Short-Term Experiments. Experiments were initiated in 1992 and again in 1998 to specifically measure root:shoot biomass ratios in typical crop rotations found in the PNW. Winter crops were seeded the last week of September and harvested the second week of July. Belowground and aboveground plant development was evaluated for WW, spring wheat (SW), SP, and WC (table 1). WW was grown near Pendleton using no-till and conventional tillage methods; SW, SP, and WC were grown using conventional tillage methods. WW crops near Pullman were grown annually under conventional practices, burn low till practices where crop residue was burned followed by a fertilizer injector and double-disk drill (McCool et al. 2008), and no-till practices. SP were grown near Pullman using conventional tillage. Using the short-term data set, we examined root and attached belowground biomass and vertical distribution, and root:shoot biomass ratios for soft white WW and SW, SP, and WC.

Spring crops were sampled three times, four replications each time, at approximately 3-leaf, anthesis, and harvest for SW and at 3-leaf (6 to 7 node), flowering (12 to 14 node), and harvest for SP. Winter crops were sampled four times, at approximately 3-leaf, 6-leaf, anthesis, and harvest for WW, and at rosette, bolting, flowering, and harvest for WC. Phenologic sampling was not conducted near Pullman in 1993 and 1994.

Core samples were collected using a 0.032 $\mathrm{m}^{2}$ (50.2 $\left.\mathrm{in}^{2}\right)$ (18 by $18 \mathrm{~cm}$ [7.1 by $\left.\left.7.1 \mathrm{in}\right]\right)$ stainless steel coring device, $61 \mathrm{~cm}$ (24 in) long, with one removable side. The coring device was inserted as far as possible into the soil and extracted using a Giddings soil probe (Giddings Machine Company Inc., Windsor, Colorado) modified to accept the coring device (Belford et al. 1987). Metal pins, 1.5 $\mathrm{mm}$ (0.06 in) diameter, were inserted into the core from the open side of the tube to dissect the soil core at $10 \mathrm{~cm}$ (3.9 in) intervals, resulting in $3.16 \times 10^{-3} \mathrm{~m}^{3}\left(0.11 \mathrm{ft}^{3}\right)$ soil volume increments containing roots and crown material. All aboveground plant material was removed from the cores, and loose soil was washed from each sample with a gentle stream of water. Roots and crown material retained on a $1.168 \mathrm{~mm}$ (0.05 in) sieve were saved as the belowground portion of the plant. Roots and crown material were separated by placing the samples in a small plastic boat, wetting and backlighting the sample, and picking out the component parts with tweezers. Roots less than $5 \mathrm{~mm}$ (0.2 in) in length were ignored. This procedure was completed in less than 8 hours to prevent substantial hydration of the plant material. Roots and crown material were kept separate, with all samples oven dried for 24 hours at $60^{\circ} \mathrm{C}\left(140^{\circ} \mathrm{F}\right)$ and weighed to the nearest $0.001 \mathrm{~g}\left(3.5 \times 10^{-5} \mathrm{oz}\right)$. 


\section{Figure 2}

Belowground development of (a) crown and root material in a wheat plant. Crown growth consists of (b) the crown, crown roots, and subcrown internode to the scutellum. The length of the subcrown internode depends on the depth of seed placement when planted. Below the seed are the seminal roots.

(a)

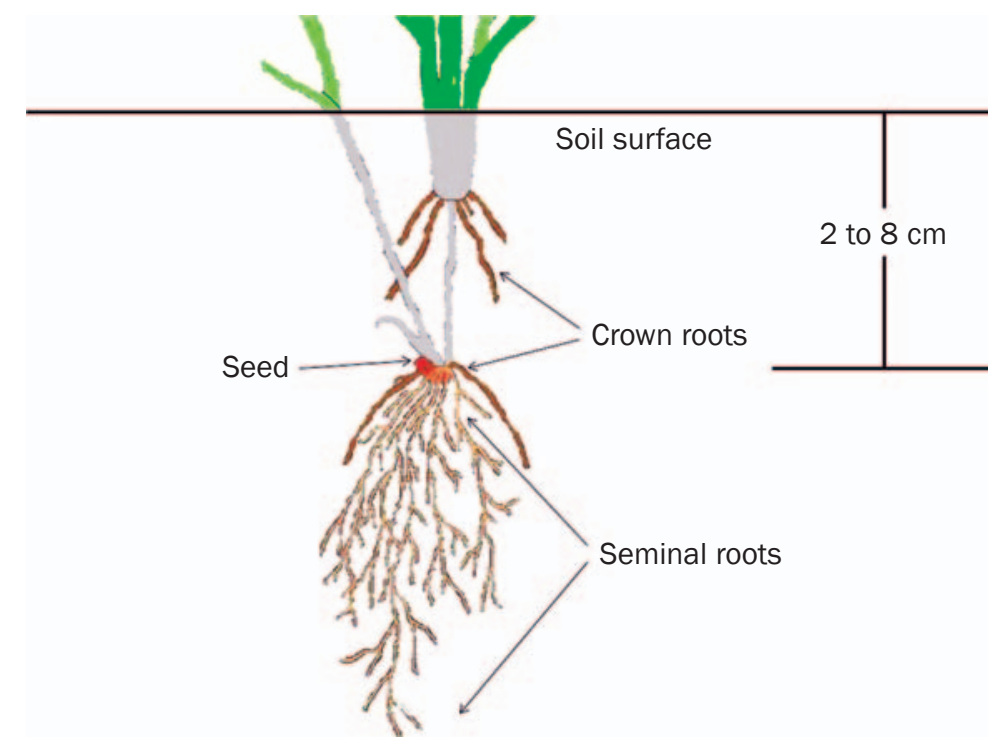

(b)

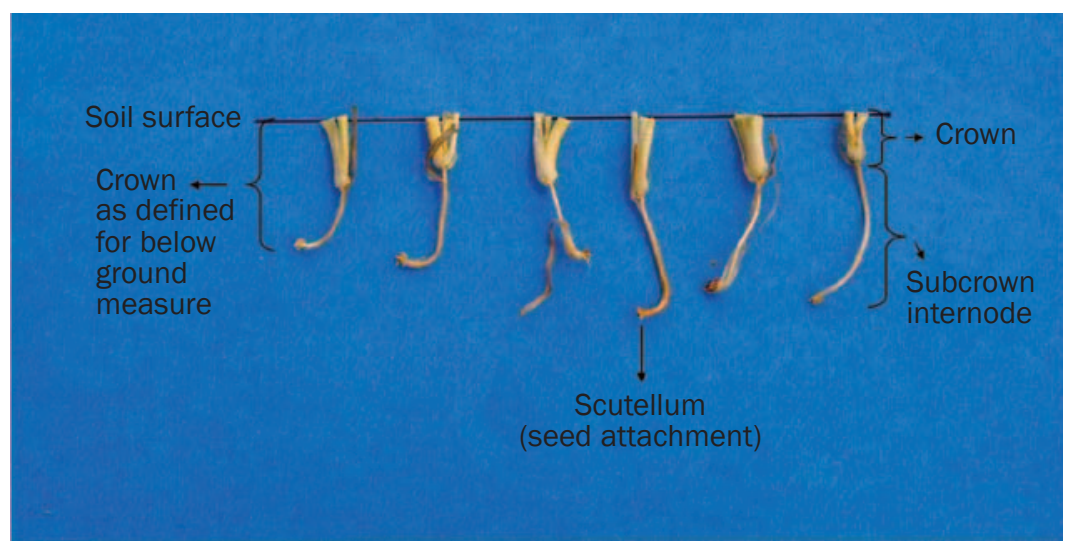

Ash contents were not measured to determine soil contamination with the assumption that soil particles remaining on the root and crown material would not substantially influence our results. Janzen et al. (2002) suggest this technique can lead to substantial errors, especially when comparisons are made among differing soil or plant types. Thus, we recommend caution when making such comparisons with this data.

Long-Term Experiments. USDA CPCRC and OSU CBARC have a number of ongoing, long-term experiments with multiple management treatments and goals (Rasmussen et al. 1994). To evaluate the effect of long-term tillage systems on residue and root distribution with depth at harvest, material) was determined for each $2.54 \mathrm{~cm}$ (1 in) increment.

Sample Collection and Analysis. Differences in biomass between depths and sampling years were evaluated at $p=0.05$, using the sign test if there were greater than 12 pairs of observations and using Wilcoxon signed rank test if there were less than 12 pairs of observations (Steele and Torrie 1960).

\section{Results and Discussion}

Short-Term Experiment Crop Production. In this semiarid region, variability in the timing and amount of annual precipitation is expected, with a corresponding fluctuation in crop yields (Schillinger 2011). Fall crops are especially dependent on late summer and fall precipitation for germination and stand vigor. Despite relatively dry falls in 1993 and 1994 at both Pendleton and Pullman (figure 1), the range of values for crop residue and grain yields reported in table 3 compare well with values reported by the USDA National Agricultural Statistics Service (USDA NASS 2012).

Short-Term Experiment Phenology and Belowground Growth. Seeding depths for the plots at Pendleton and Pullman are listed in table 4, along with the crown depths for WW and SW. Seeding depth for WW at Pendleton ranged from 2.6 to $5.2 \mathrm{~cm}$ (1 to $2 \mathrm{in}$ ), and crown depth from 2 to $2.5 \mathrm{~cm}$ (0.8 to 1 in). Pullman WW seeding depth ranged from 2.2 to $3.4 \mathrm{~cm}$ (0.9 to $1.3 \mathrm{in}$ ), and crown depth was 1.7 to $2.9 \mathrm{~cm}$ (0.7 to $1.1 \mathrm{in}$ ). Pendleton SW seeding depth was $4 \mathrm{~cm}$ (1.6 in), and crown depth was $2.4 \mathrm{~cm}$ (0.9 in). While seeding depth can vary with a number of factors, such as amount and type of tillage and drill pressure, crown depth was less variable in these studies. Seeding depth for SP was 5.1 $\mathrm{cm}$ (2 in) at Pendleton and $4.1 \mathrm{~cm}$ (1.6 in) at Pullman. Although SP have no crown, the belowground stem material above the seed and the root system can be substantial.

Total biomass in the upper 0 to $10 \mathrm{~cm}(0$ to 3.9 in) layer in the soil declined after anthesis in WW and was unchanged for SW. In both cases, root growth continued as crown mass decreased (table 5). Campbell et al. (1977) reported similar results for loss of mass in SW roots between anthesis and maturity but did not differentiate between crowns and roots. The loss of crown mass as the plants senesce is possibly the result of substantial soil drying due to the nearly total lack of precipitation from early June through September in this region. Contrary to early reports that cereal 


\section{Table 1}

Location, crop, crop variety, seeding date and other selected information for plant samples collected in the short-term study near Pendleton, Oregon, and Pullman, Washington.

\begin{tabular}{|c|c|c|c|c|c|}
\hline Location & Crop & Variety & Seeding date & Harvest & Management notes \\
\hline \multicolumn{6}{|l|}{ Pendleton } \\
\hline & WW & Stephens & Sept. 30, 1992 & 1993 & No-till, after WW \\
\hline & SW & Penewawa & Mar. 31, 1993 & 1993 & Conventional, after WW \\
\hline & SW & Penewawa & Mar. 23, 1994 & 1994 & Conventional, after WW \\
\hline & WC & Arabella & Aug. 31, 1992 & 1993 & Conventional, after fallow \\
\hline & SP & Dual & Apr. 14, 1993 & 1993 & Conventional, after WW \\
\hline & SP & Dual & Mar. 31, 1994 & 1994 & Conventional, after WW \\
\hline & WW & Stephens & Oct. 20,1998 & 1999 & Conventional, continuous WW \\
\hline & WW & Stephens & Oct. 15,1998 & 1999 & No-till, continuous WW \\
\hline & WW & Stephens & Oct. 20, 1999 & 2000 & Conventional, after fallow \\
\hline & WW & Madsen & Oct. 10, 1993 & 1994 & No-till, after WW \\
\hline & SP & Columbia B-160 & May 19, 1993 & 1993 & Conventional, after WW \\
\hline & SP & Columbia B-160 & May 3, 1994 & 1994 & Conventional, after WW \\
\hline & WW & Madsen & Oct. 15, 1994 & 1995 & Burn, low till, after WW \\
\hline & WW & Madsen & Oct. 15,1994 & 1995 & Conventional, after WW \\
\hline
\end{tabular}

Notes: WW = winter wheat. SW = spring wheat. WC = winter canola. SP = spring pea. No-till = seed and fertilize in one equipment pass. Conventional, after WW = plow after harvest, cultivate, and seed. Conventional, after fallow = plow in fall, cultivate in spring, rod weed two to four times during summer. Burn, low till = burn, cultivate (fertilizer injector), and seed in fall after WW harvest.

\section{Table 2}

Experiment name, rotation, tillage, and duration of experiment for long-term plots sampled near Pendleton, Oregon.

\begin{tabular}{llll}
\hline Experiment name & Rotation & Seedbed tillage & Experiment duration $(\mathbf{y})$ \\
\hline CR & WW/F & MBP, FC, RW & 71 \\
CWW & Annual crop WW & MBP, FC, RW & 71 \\
NT & WW/CF & None & 14 \\
WP & WW & FC, RW & \\
& SP & MBP, FC & 39 \\
\hline
\end{tabular}

Notes: $\mathrm{CR}=$ crop residue. $\mathrm{CWW}=$ continuous winter wheat. $\mathrm{NT}=$ no-till. $\mathrm{WP}=$ winter wheat/ spring pea. $\mathrm{WW}=$ winter wheat. $\mathrm{F}=$ summer fallow, tilled. $\mathrm{CF}=$ summer fallow, chemical. $\mathrm{SP}=$ spring pea. $\mathrm{MBP}=$ moldboard plow. $\mathrm{FC}=$ field cultivate. $\mathrm{RW}=$ rod weed .

roots do not grow during seed ripening (Russell 1961), our data show that cereal root mass increased until harvest, as did the root systems in the WC (table 5). Belowground WC biomass, consisting entirely of roots, increased slightly between flowering and maturity, whereas belowground SP biomass decreased between 12 to 14 node and maturity; most of the loss was in root mass while belowground stem increased slightly.

Crown mass of WW and SW at harvest accounted for $32 \%$ and $45 \%$, respectively, of the biomass in the upper $10 \mathrm{~cm}$ (3.9 in) layer of the soil, with the balance composed of seminal roots. In SP, stem material between the seed and soil surface accounted for 38\% of the biomass. Belowground biomass of WC consisted of roots without stem or crown material. Our experimental data showed that the cereal crowns were within $2.5 \mathrm{~cm}$ (1 in) of the soil surface. At this depth, crowns and attached belowground stem material from a harvested crop can be important in protecting the soil from erosion, especially when no-till seeding practices are used and the crowns are anchored to the soil by the crown root system.

Short-Term Experiment Root Mass Distribution with Depth. A complete set of incremental $10 \mathrm{~cm}$ (3.9 in) data from 0 to $40 \mathrm{~cm}$ (0 to $15.7 \mathrm{in}$ ) was only collected near Pendleton. The higher clay content soil near Pullman proved too hard to sample consistently to depth at harvest after the soil had dried and hardened. WC had significantly more and SP had significantly less biomass in the 0 to $10 \mathrm{~cm}$ (0 to 3.9 in) soil depth than the other crops (table 6). At harvest, 70\% of WW, SW, and WC biomass in samples collected to $61 \mathrm{~cm}$ (24 in) was at depths shallower than $10 \mathrm{~cm}$ (3.9 in) (table 7 and figure 3 ). In SP, $70 \%$ of roots were at depths shallower than $18 \mathrm{~cm}$ (7.1 in), and roots and belowground stems shallower than $15 \mathrm{~cm}$ (5.9 in) of the soil surface (figure 3 ). Root mass distribution among all treatments of WW and SW were statistically indistinguishable at any depth. WC had greater belowground biomass (tables 5 and 6) and the greatest aboveground residue mass (table 3) of all crops at all stages and depths through harvest. WC biomass percentage in the upper $10 \mathrm{~cm}$ is highest of all crops (table 7). 
Table 3

Aboveground biomass at harvest of short-term experiments in dryland crops grown near Pendleton, Oregon, and Pullman, Washington.

\begin{tabular}{|c|c|c|c|c|c|}
\hline Location & Crop & Year and management & $\begin{array}{l}\text { Grain* } \\
\left(\text { Mg ha }^{-1}\right)\end{array}$ & $\begin{array}{l}\text { Residue } \\
\left(\mathrm{Mg} \mathrm{ha}^{-1}\right)\end{array}$ & $\begin{array}{l}\text { Total aboveground } \\
\text { biomass } \\
\left(\mathrm{Mg} \mathrm{ha}^{-1}\right)\end{array}$ \\
\hline \multirow[t]{3}{*}{ Pendleton } & WW & 1993, 1994: no-till, annual crop & $4.60 \pm 0.78$ & $7.16 \pm 2.14$ & $11.76 \pm 2.92$ \\
\hline & & 1999: no-till continuous & $4.62 \pm 0.35$ & $6.23 \pm 0.19$ & $10.85 \pm 0.69$ \\
\hline & & 2000: conventional after fallow & $5.74 \pm 0.42$ & $10.96 \pm 0.80$ & $16.70 \pm 1.22$ \\
\hline & & 1995: burn low till, annual crop & $6.19 \pm 1.31$ & $7.97 \pm 2.05$ & $14.16 \pm 3.36$ \\
\hline Pendleton & WC & 1993, 1994: conventional, after fallow & $1.80 \pm 0.29$ & $13.89 \pm 0.23$ & $15.70 \pm 0.05$ \\
\hline Pendleton & SW & $\begin{array}{l}\text { 1993, 1994: conventional tillage, annual crop; } 2000 \text { : } \\
\text { no-till, annual crop }\end{array}$ & $2.75 \pm 0.54$ & $4.94 \pm 1.56$ & $7.70 \pm 1.15$ \\
\hline Pendleton & SP & 1993, 1994: conventional, after WW & $3.81 \pm 0.46$ & $4.39 \pm 0.62$ & $8.20 \pm 0.17$ \\
\hline
\end{tabular}

\section{Table 4}

Crown and seed depths measured at harvest near Pendleton, Oregon, and Pullman, Washington.

\begin{tabular}{lllll}
\hline Location & Crop & Year and management & Seed depth (cm) & Crown depth (cm) \\
\hline Pendleton & WW & 1993, 1994: no-till, annual crop & $5.19 \pm 0.71$ & $1.96 \pm 0.49$ \\
& & 1999: conventional, continuous & NA & NA \\
& & 1999: no-till continuous & NA & NA \\
& & 2000: conventional after fallow & $2.60 \pm 0.50$ & $2.52 \pm 0.49$ \\
\hline Pullman & WW & 1993, 1994: no-till, annual crop & $3.42 \pm 1.16$ & $1.72 \pm 0.04$ \\
& & 1995: conventional moldboard plow, annual crop & $3.43 \pm 1.25$ & $2.93 \pm 1.07$ \\
& & 1995: burn low till, annual crop & $2.23 \pm 0.76$ & $1.92 \pm 0.65$ \\
\hline Pendleton & SW & 1993, 1994: conventional tillage, annual crop; 2000: no-till, annual crop & $4.01 \pm 0.15$ & $2.41 \pm 0.37$ \\
\hline Pendleton & SP & 1993, 1994: conventional, after WW & $5.07 \pm 1.10$ & NA \\
\hline Pullman & SP & 1993, 1994: conventional, after WW & $4.08 \pm 0.70$ & NA \\
\hline
\end{tabular}

Notes: $\mathrm{WW}=$ winter wheat. $\mathrm{SW}=$ spring wheat. $\mathrm{WC}=$ winter canola. $\mathrm{SP}=$ spring peas.

Given the difference in precipitation and temperatures between Pendleton and Pullman, we expected to find differences among the crops grown at each site. However, the similar values are likely due to the convergence of weather conditions during the relatively short time period that these measurements were taken. Weather also likely played a role in the relatively large difference in WC root mass in the 0 to $10 \mathrm{~cm}$ (0 to 3.9 in) soil depth; in 1993, we measured $2.66 \mathrm{Mg}$ $\mathrm{ha}^{-1}\left(5.97 \mathrm{tn} \mathrm{ac}^{-1}\right)$, and in 1994, we measured 4.11 $\mathrm{Mg} \mathrm{ha}^{-1}$ (9.21 tn ac ${ }^{-1}$ ) (data not shown).

Short-Term Experiment Phenology, Belowground Biomass, and Root:Shoot Ratios. Root:shoot ratios at Pendleton in the top $40 \mathrm{~cm}$ (15.7 in) at harvest (table 8) were larger than the root:shoot value of 0.08 determined for a $20 \mathrm{~cm}$ (7.9 in) soil depth found by Barraclough et al. (1991) and similar to root:shoot values of 0.15 to 0.09 found from near the surface to a depth of $30 \mathrm{~cm}$ (11.8 in) by Gregory et al. (1978) for WW in the UK. Our values are also similar to values sampled to depths of $30 \mathrm{~cm}$ (11.8 in) and reported by Bolinder et al. (1997) from sites in Ontario and Québec, Canada, of 0.14 and 0.2 for WW at two sites and where $70 \%$ of the root mass was found to a depth of 15 cm (5.9 in). In Saskatchewan, Canada, where sampling was done to depths of $60 \mathrm{~cm}(23.6$ in), Campbell et al. (1977) reported values of
0.14 for SW, and Gan et al. (2009) reported values of 0.24 for canola and 0.16 for wheat. In central Alberta, Canada, Izaurralde et al. (1993) reported ratios of 0.12 for spring barley (Hordeum vulgare L.) sampled to a depth of $40 \mathrm{~cm}$ (15.7 in), similar to the values we report for SW. Our values for small grain, oil seed, or pulse crops are all considerably smaller than those of Buyanovsky and Wagner (1986) who reported a root:shoot ratio of 0.88 for WW in Missouri in a $50 \mathrm{~cm}$ (19.7 in) soil depth, with $75 \%$ of the mass within $10 \mathrm{~cm}$ (3.9 in) of the soil surface. Wheat root:shoot ratios as low as 0.1 in the surface $10 \mathrm{~cm}$ (3.9 in) have been reported under conditions of adequate soil water and 
Table 5

Phenologic development of root and crown mass for cereal grains and belowground stem and root mass for the o to $10 \mathrm{~cm}$ soil depth for all crops in 1993 and 1994 near Pendleton, Oregon.

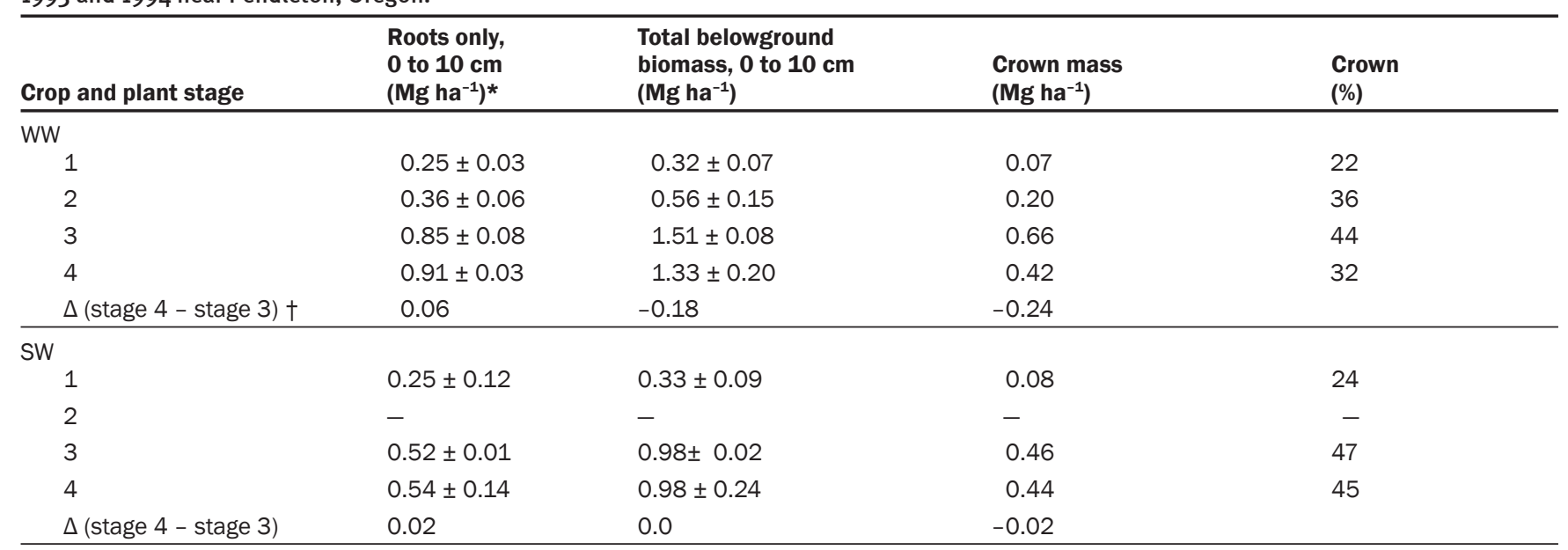

WC

$\begin{array}{lll}1 & 0.50 \pm 0.05 & 0.50 \pm 0.05 \\ 2 & 1.06 \pm 0.37 & 1.06 \pm 0.37 \\ 3 & 3.62 \pm 0.49 & 3.62 \pm 0.49 \\ 4 & 3.64 \pm 0.98 & 3.64 \pm 0.98 \\ \Delta \text { (stage 4 - stage 3) } & 0.02 & 0.02\end{array}$

\begin{tabular}{|c|c|c|c|c|}
\hline & & & $\begin{array}{l}\text { Belowground stem } \\
\left(\mathrm{Mg} \mathrm{ha}^{-1}\right)\end{array}$ & $\begin{array}{l}\text { Belowground stem } \\
\text { (\%) }\end{array}$ \\
\hline \multicolumn{5}{|l|}{$\mathrm{SP}$} \\
\hline 1 & $0.14 \pm 0.07$ & $0.21 \pm 0.07$ & 0.07 & 33 \\
\hline 3 & $0.21 \pm 0.07$ & $0.28 \pm 0.06$ & 0.07 & 25 \\
\hline 4 & $0.16 \pm 0.02$ & $0.26 \pm 0.01$ & 0.10 & 38 \\
\hline
\end{tabular}

Notes: $\mathrm{WW}=$ winter wheat. $\mathrm{SW}=$ spring wheat. $\mathrm{WC}=$ canola. SP $=$ spring peas.

* Values are means and standard error of four replications each year (1993 and 1994): for WW, 1 = 3-leaf, 2 = 5-leaf, 3 = anthesis, and 4 = harvest; for SW, 1 = 3-leaf, $2=-, 3=$ anthesis, and 4 = harvest.

† Change in mass from stage 3 (anthesis in wheat, flowering in canola, and 12 to 14 node in spring pea) to harvest.

moderate temperatures and as high as 0.5 where nitrogen $(\mathrm{N})$ and soil water were limiting factors, with a midrange value in the mid-0.2s (Bolinder et al. 1997; Hamblin et al. 1990). Still lower ratios of biomass have been reported for WW grown in Sweden (Kätterer et al. 1993), with ratios at harvest of 0.04 to a depth of $50 \mathrm{~cm}$ (19.7 in) under rainfed conditions. These differing values can be the result of different growing conditions, such as fewer growing degree-days due to planting dates and latitude; fertilizer application rates and methods; and differences in precipitation patterns among Mediterranean, continental, and maritime climates. Kätterer et al. (1993) also corrected for ash content, which would result in as much as $10 \%$ lower values than they reported.

Long-Term Experiment Aboveground and Belowground Biomass. Mean annual aboveground residue and crop yields in the long-term experiments did not differ substantially from values found for the same or similar crops in the short-term experiments (table 3 and table 9). Aboveground residue deceased in the following order: CWW > $\mathrm{NT}>\mathrm{CR}>$ WP. Sampled belowground biomass was CWW $>\mathrm{CR}>\mathrm{WP}>\mathrm{NT}$ (table 10). At opposite ends of aboveground residue productivity, the CWW returned more residue to the soil than WP because SP produced less residue and these residues were incorporated with a field cultivator rather than a moldboard plow.

Greater than $70 \%$ of sampled belowground biomass was in the first 15 to 20 $\mathrm{cm}$ (5.9 to 7.9 in) of the soil surface from $31 \mathrm{~cm}$ (12 in) samples in CWW, WP, and CR (table 11 and figure 4). This is within the zone where mixing by tillage opera- tions occurs. Alternatively, with no mixing of belowground root or stem material and limited disturbance of wheat crowns, nearly $70 \%$ of the belowground material in the NT is within $5 \mathrm{~cm}$ (2 in) of the surface.

\section{Summary and Conclusions}

We found for the tillage operations and seeding depths in our study that greater than $70 \%$ of total WW belowground biomass produced within $61 \mathrm{~cm} \mathrm{(24} \mathrm{in)} \mathrm{of} \mathrm{the} \mathrm{soil}$ surface is in the top $15 \mathrm{~cm}$ (5.9 in) of soils at harvest in combinations of no-till and conventional tillage. This is approximately the same for SW and WC, but somewhat less for SP. Although we have personally identified WW roots below $150 \mathrm{~cm}$ (59.1 in), we suggest that with greater than $80 \%$ of the root mass above $20 \mathrm{~cm}$ (7.9 in) for the crops we sampled, sampling below 30 or $40 \mathrm{~cm}(11.8$ 


\section{Table 6}

Belowground biomass at harvest for dryland crops grown near Pendleton, Oregon, and Pullman, Washington.

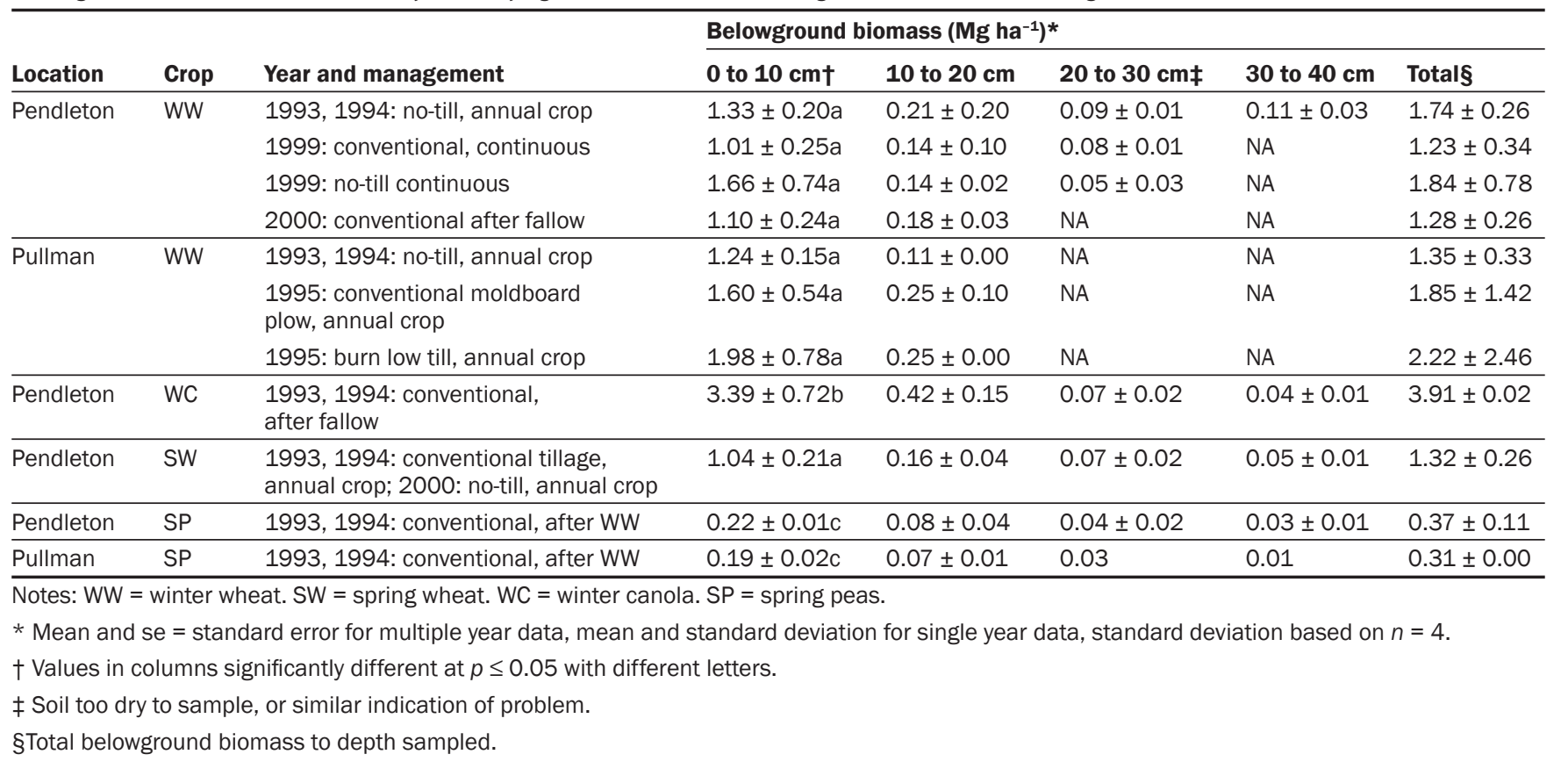

or 15.7 in) is unnecessary. These findings are in agreement with RUSLE2 Science Documentation (USDA ARS 2008), which indicates that an average of $74 \%$ of root mass is in the upper $15 \mathrm{~cm}$ (5.9 in) of the profile.

Our data showed that the crowns of WW and SW were within $2.5 \mathrm{~cm}$ (1 in) of the soil surface and made up $32 \%$ and $45 \%$, respectively, of the belowground biomass in the upper $10 \mathrm{~cm}$ (3.9 in) of the soil. At this depth, crowns and attached belowground stem material from a crop from which stubble has been removed can be important in protecting the soil from erosion in the following crop. When no-till seeding practices are used, the crowns and their aboveground stem clumps remain anchored to the soil by the crown root system. WC provided an even higher root mass in the upper 10 $\mathrm{cm}$ of the soil, which was very durable and would provide a high level of erosion resistance if a following crop is seeded using no-till practices.

The variability in root:shoot biomass ratios in wheat from 1993 through 2000 at Pendleton and Pullman was modest relative to values reported in the literature. Values in the Pendleton short-term experiments in $30 \mathrm{~cm}$ (11.8 in) profiles varied from 0.13 to 0.17 ; combined Pendleton and Pullman $10 \mathrm{~cm}$ (3.9 in) profile data produced a mean root:shoot ratio of 0.10 .

\section{Table 7}

Belowground biomass distribution at harvest as a percentage of mass by depth for dryland crops measured in 1993 and 1994 near Pendleton, Oregon.

\begin{tabular}{lllll}
\hline & \multicolumn{4}{l}{ Belowground biomass (\%) } \\
\cline { 2 - 5 } Experiment* & $\mathbf{0}$ to $\mathbf{1 0} \mathbf{~ c m}$ & $\mathbf{0}$ to $\mathbf{2 0} \mathbf{~ c m}$ & $\mathbf{0}$ to $\mathbf{3 0} \mathbf{~ c m}$ & $\mathbf{0}$ to $\mathbf{4 0} \mathbf{~ c m}$ \\
\hline WW & 76 & 89 & 94 & 100 \\
SW & 78 & 88 & 96 & 100 \\
WC & 89 & 98 & 99 & 100 \\
SP & 60 & 82 & 93 & 100 \\
\hline
\end{tabular}

Notes: $\mathrm{WW}=$ winter wheat, $\mathrm{SW}=$ spring wheat, $\mathrm{WC}=$ winter canola, and $\mathrm{SP}=$ spring wheat.

* Mean of all sites and tillage practices.

The distribution of belowground biomass in the soil in the long-term study to depths we sampled showed that biomass in CWW plots was homogenized through the plow layer and greater than in CR and NT. This is not unexpected, considering that CWW has a WW crop every year with inversion tillage, whereas CR has a WW crop every other year with inversion tillage, and while in fallow, plant material is subject to microbial consumption. NT has a WW crop every other year with chemical fallow and no-till seeding. WP has alternating high/low residue levels with the mixing of soil and residue by moldboard plow inversion and surface mixing following pea harvest with a field cultivator. Distribution and amount of belowground biomass is a function of tillage method and cropping frequency.

Accurately accounting for this material in soil erosion models is critical for the proper functioning of the model. The default value currently suggested for use in WEPP for a wheat root:shoot ratio, 0.25 (USDA ARS 1995), is high relative to the values we report here, whether from $10 \mathrm{~cm}$ (3.9 in) or $30 \mathrm{~cm}$ (11.8 in) soil profiles. Many more years of data might result in a shift upward in these values, but by fixing this parameter the yearto-year variability that can occur as the result of changes in fertilizer applications (Paustian et al. 1990) and regularly experienced crop year droughts, the effect roots have on soil erosion and the contribution to soil organic matter can be misrepresented 


\section{Figure 3}

Belowground biomass distribution at harvest as a percentage of mass by depth for dryland crops measured in 1993 and 1994 near Pendleton, Oregon: (a) winter wheat, (b) winter canola, (c) spring wheat, and (d) spring pea. All crops except spring peas have over $70 \%$ of the root mass within $15 \mathrm{~cm}$ of the soil surface; spring peas have $70 \%$ within $18 \mathrm{~cm}$ of the soil surface. Values are the mean of four replications.

(a)

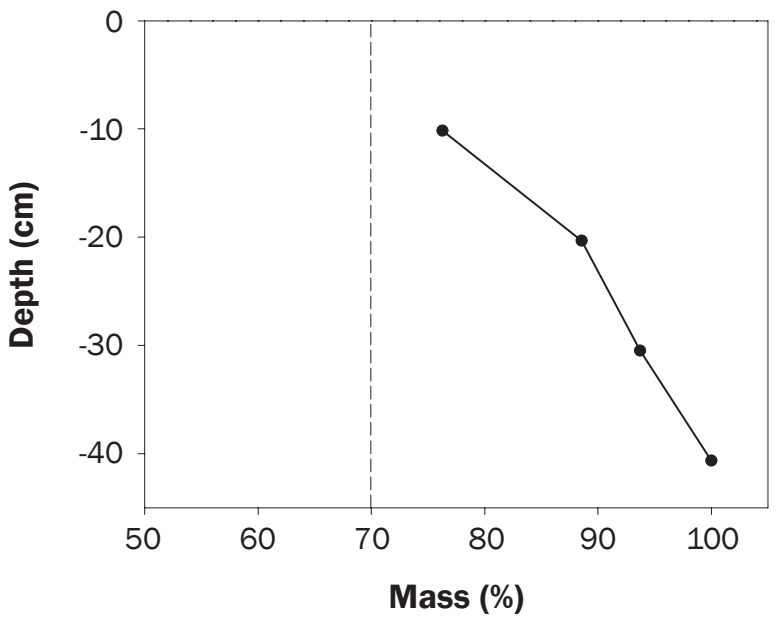

(c)

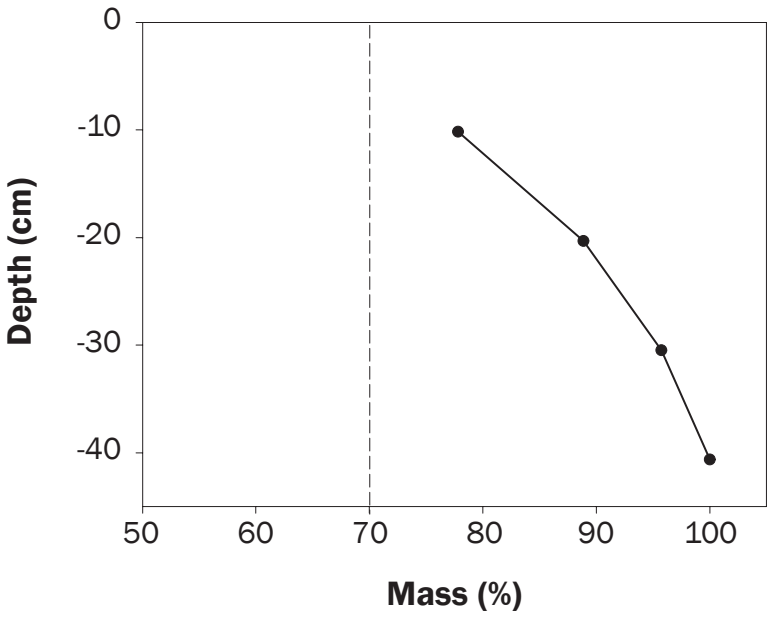

(b)

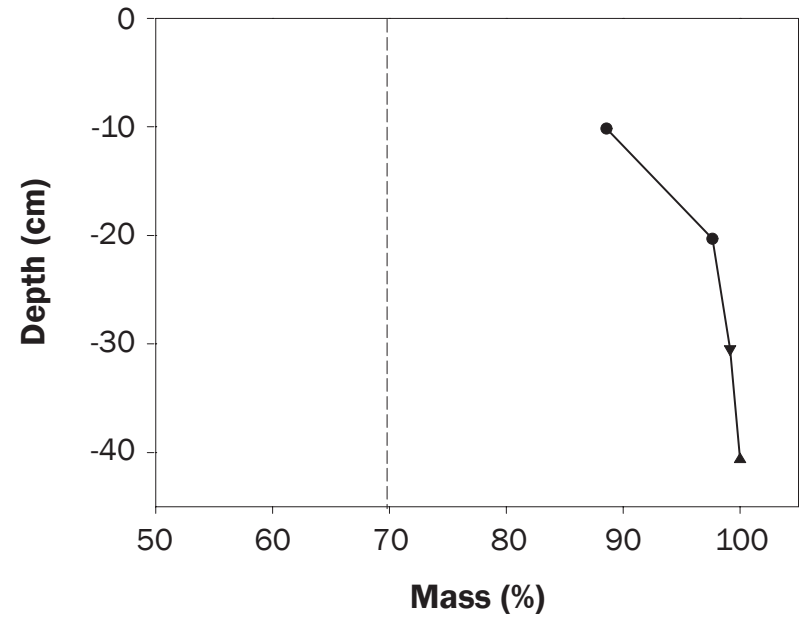

(d)

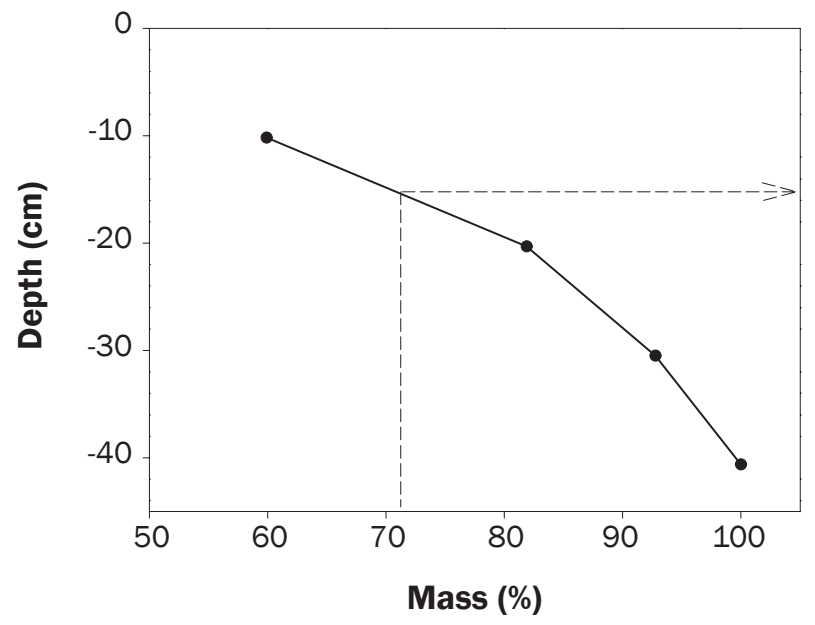

Table 8

Root:shoot ratios measured at harvest near Pendleton, Oregon, and Pullman, Washington.

\begin{tabular}{|c|c|c|c|c|c|c|}
\hline \multirow[b]{2}{*}{ Location } & \multirow[b]{2}{*}{ Crop } & \multirow[b]{2}{*}{ Year and management } & \multicolumn{4}{|c|}{ Root:shoot ratio } \\
\hline & & & 0 to $10 \mathrm{~cm}$ & 0 to $20 \mathrm{~cm}$ & 0 to $30 \mathrm{~cm}$ & 0 to $40 \mathrm{~cm}$ \\
\hline \multirow[t]{4}{*}{ Pendleton } & WW & 1993, 1994: no-till, annual crop & 0.11 & 0.13 & 0.14 & 0.15 \\
\hline & & 1999: conventional, continuous & 0.11 & 0.12 & 0.13 & NA \\
\hline & & 1999: no-till continuous & 0.15 & 0.17 & 0.17 & NA \\
\hline & & 2000: conventional after fallow & 0.07 & 0.08 & NA & NA \\
\hline \multirow[t]{3}{*}{ Pullman } & WW & 1993, 1994: no-till, annual crop & 0.15 & 0.15 & NA & NA \\
\hline & & 1995: conventional moldboard plow, annual crop & 0.09 & 0.11 & NA & NA \\
\hline & & 1995: burn low till, annual crop & 0.14 & 0.16 & NA & NA \\
\hline Pendleton & WC & 1993, 1994: conventional, after fallow & 0.22 & 0.24 & 0.25 & 0.26 \\
\hline Pendleton & SW & $\begin{array}{l}\text { 1993, 1994: conventional tillage, annual crop; } \\
\text { 2000: no-till, annual crop }\end{array}$ & 0.13 & 0.16 & 0.17 & 0.17 \\
\hline Pendleton & SP & 1993, 1994: conventional, after WW & 0.03 & 0.04 & 0.04 & 0.05 \\
\hline Pullman & SP & 1993, 1994: conventional, after WW & 0.06 & 0.07 & NA & NA \\
\hline
\end{tabular}

Notes: $\mathrm{WW}=$ winter wheat. $\mathrm{SW}=$ spring wheat. $\mathrm{WC}=$ winter canola. $\mathrm{SP}=$ spring peas. 


\section{Table 9}

Crop yields in long-term experiments during years of belowground data collection at Pendleton, Oregon.

\begin{tabular}{|c|c|c|c|c|}
\hline Experiment & & $\begin{array}{l}\text { Crop yield } \\
\left(\mathrm{Mg} \mathrm{ha}^{-1}\right)^{*}\end{array}$ & $\begin{array}{l}\text { Aboveground } \\
\text { residue } \\
\left(\mathrm{Mg} \mathrm{ha}^{-1}\right)\end{array}$ & $\begin{array}{l}\text { Total aboveground } \\
\text { biomass } \\
\left(\mathrm{Mg} \mathrm{ha}^{-1}\right) \dagger\end{array}$ \\
\hline NT & & $4.89 \pm 0.43$ & 4.86 & 9.75 \\
\hline \multirow[t]{3}{*}{ WP } & WW & $4.66 \pm 0.63$ & 3.68 & 8.34 \\
\hline & $\mathrm{SP}$ & $2.09 \pm 0.27$ & 2.68 & 2.09 \\
\hline & Mean & 3.38 & 3.18 & 6.56 \\
\hline CWW & & $4.20 \pm 0.65$ & 6.88 & 11.08 \\
\hline $\mathrm{CR}$ & & $4.73 \pm 0.35$ & 4.33 & 9.06 \\
\hline
\end{tabular}

Notes: NT $=$ no-till winter wheat. WP $=$ winter wheat $(\mathrm{WW})$ and spring peas (SP). CWW $=$ continuous winter wheat. $\mathrm{CR}=$ crop residue.

* Mean crop yield from years corresponding to years of data collection in short-term experiments (1993, 1994, 1995, 1999, and 2000).

† Aboveground straw and residue for crop year, experiment station records without original data to calculate error values.

\section{Table 10}

Total belowground biomass and distribution by depth for four long-term plots located at the USDA Columbia Plateau Conservation Research Center and the Oregon State University Columbia Basin Agricultural Research Center Pendleton, Oregon.

\begin{tabular}{lllll}
\hline & \multicolumn{4}{l}{ Belowground biomass $\mathbf{( M g}$ ha-1) } \\
\cline { 2 - 5 } Experiment* & $\mathbf{0}$ to $\mathbf{1 0} \mathbf{~ c m}$ & $\mathbf{1 0}$ to $\mathbf{2 0} \mathbf{~ c m}$ & $\mathbf{2 0}$ to $\mathbf{3 0} \mathbf{~ c m}$ & Total \\
\hline NT & $2.41 \pm 0.49$ & $0.25 \pm 0.03$ & $0.05 \pm 0.00$ & $2.73 \pm 0.61 \mathrm{a}$ \\
WP & $2.98 \pm 0.20$ & $1.70 \pm 0.17$ & $0.23 \pm 0.04$ & $4.91 \pm 1.21 \mathrm{~b}$ \\
CWW & $3.42 \pm 0.20$ & $2.44 \pm 0.21$ & $0.26 \pm 0.03$ & $6.31 \pm 0.94 \mathrm{c}$ \\
CR & $2.76 \pm 0.19$ & $2.65 \pm 0.53$ & $0.22 \pm 0.04$ & $5.63 \pm 3.91 \mathrm{~b}$ \\
\hline
\end{tabular}

Notes: NT = no-till winter wheat. WP $=$ winter wheat, spring peas. $\mathrm{CWW}=$ continuous winter

wheat. $\mathrm{CR}=$ crop residue.

* Mean and standard deviation, $n=4$.

† Values in columns significantly different at $p \leq 0.05$ with different letters.

\section{Table 11}

Total belowground biomass distribution as a percentage of mass by depth for long-term experiments near Pendleton, Oregon.

\begin{tabular}{llll}
\hline \multirow{2}{*}{ Experiment } & \multicolumn{3}{l}{ Belowground biomass (\%) } \\
\cline { 2 - 4 } $\mathbf{0}$ to $\mathbf{1 0} \mathbf{~ c m}$ & $\mathbf{0}$ to $\mathbf{2 0} \mathbf{~ c m}$ & $\mathbf{0}$ to $\mathbf{3 0} \mathbf{~ c m}$ \\
\hline NT & 89 & 98 & 100 \\
WP & 61 & 96 & 100 \\
CWW & 56 & 96 & 100 \\
CR & 49 & 96 & 100
\end{tabular}

Notes: NT = no-till winter wheat. WP $=$ winter wheat, spring peas. $\mathrm{CWW}=$ continuous winter wheat. $\mathrm{CR}=$ crop residue.

in the modeling effort. For instance, WEPP can under-predict runoff and erosion in the PNW unless the hydraulic conductivity and rill erodibility parameters are calibrated (Williams et al. 2010). We speculate that use of a lower root:shoot ratio might improve the model's performance, but further evaluation to determine additional parameterization of soil properties intrinsic to the region will be needed. This adaptation would be most appropriate for winter crops, in which root mass development through the fall is critical for controlling the winter processes of soil erosion in the PNW.

\section{Acknowledgements}

We thank Tami Johlke, biological science technician; Amy Baker, biological science technician; Roger Goller, biological science technician (retired); and Noel Roager, chemist (retired); all of the Columbia Plateau Conservation Research Center, Pendleton, Oregon. We also thank Paul Mutch, hydrologic technician (retired), of Land Management and Water Conservation Research, Pullman, Washington, and numerous seasonal employees for field and laboratory help. This research was made possible through base funding through the USDA Agricultural Research Service national program Climate Change, Soils, and Emissions (NP\#212). USDA is an equal opportunity provider and employer.

\section{References}

Barraclough, P.B., A.H. Weir, and H. Kuhlmann. 1991. Factors affecting the growth and distribution of winter wheat roots under UK field conditions. Developments in Agricultural and Managed-Forest Ecology 24:410-417

Belford, R.K., B. Klepper, and R.W. Rickman. 1987. Studies of intact shoot-root Systems of field-grown winter wheat. II. root and shoot developmental patterns as related to nitrogen fertilizer. Agronomy Journal 79(2):310-319

Bolinder, M.A., D.A. Angers, and J.P. Dubuc. 1997. Estimating shoot to root ratios and annual carbon inputs in soils for cereal crops. Agriculture, Ecosystems and Environment 63(1):61-66.

Buyanovsky, G., and G. Wagner. 1986. Post-harvest residue input to cropland. Plant and Soil 93(1):57-65.

Campbell, C.A., W. Nicholaichuk, H.R. Davidson, and D.R. Cameron. 1977. Effects of fertilizer $\mathrm{N}$ and soil moisture on growth, $\mathrm{N}$ content, and moisture use by spring wheat. Canadian Journal of Soil Science 57(3):289-310.

Donaldson, N.C. 1980. Soil survey of Whitman County, Washington. Washington, DC: USDA Soil Conservation Service, US Government Printing Office.

Douglas, C.L., T.R. Toll, B.L. Klepper, and D.E. Wilkins. 1990. Identifying individual plants or plants parts during shoot and root evaluations. Agronomy Journal 82(6):1169-1170.

Ebbert, J.C., and R.D. Roe. 1998. Soil erosion in the Palouse River Basin: Indications of improvement. US Geological Survey Fact Sheet FS-069-98. Reston, VA: US Geological Survey.

Gan, Y.T., C.A. Campbell, H.H. Janzen, R.L. Lemke, P. Basnyat, and C.L. McDonald. 2009. Carbon input to soil from oilseed and pulse crops on the Canadian prairies. Agriculture, Ecosystems and Environment 132(3-4):290-297.

Gregory, P.J., M. McGowan, P.V. Biscoe, and B. Hunter. 1978. Water relations of winter wheat: 1. Growth of the root system. The Journal of Agricultural Science 91(1):91-102. 


\section{Figure 4}

Total belowground biomass with depth including incorporated crop residue, in four long-term plots at Pendleton, Oregon. Values shown are the mean of four replications. Long-term experiment names include (a) no-till, chemical fallow, (b) continuous winter wheat, inversion tillage, (c) winter wheat/spring pea, inversion tillage, and (d) crop residue, tillage fallow.

(a)

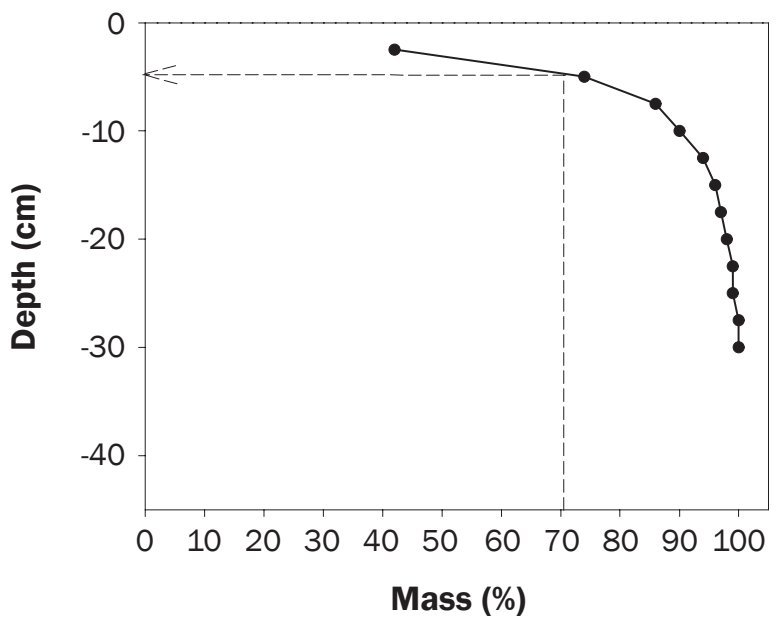

(c)

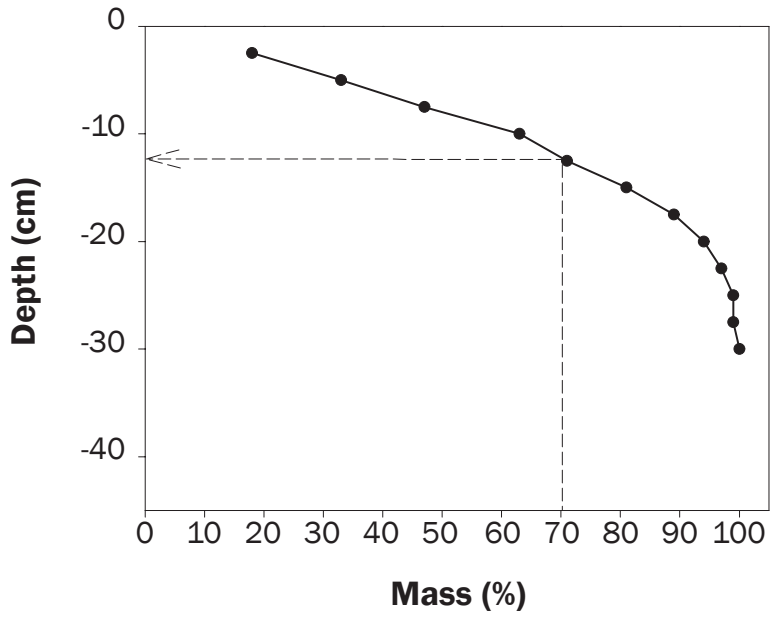

(b)

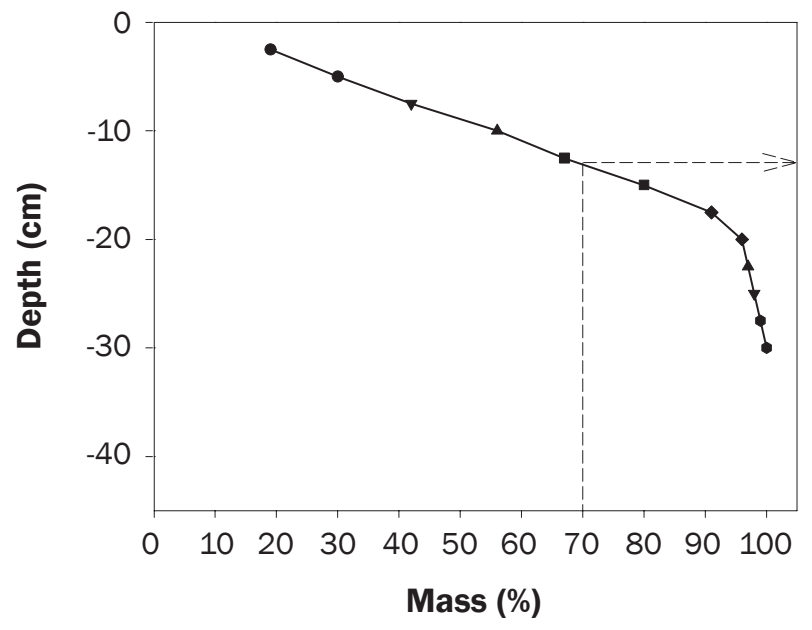

(d)

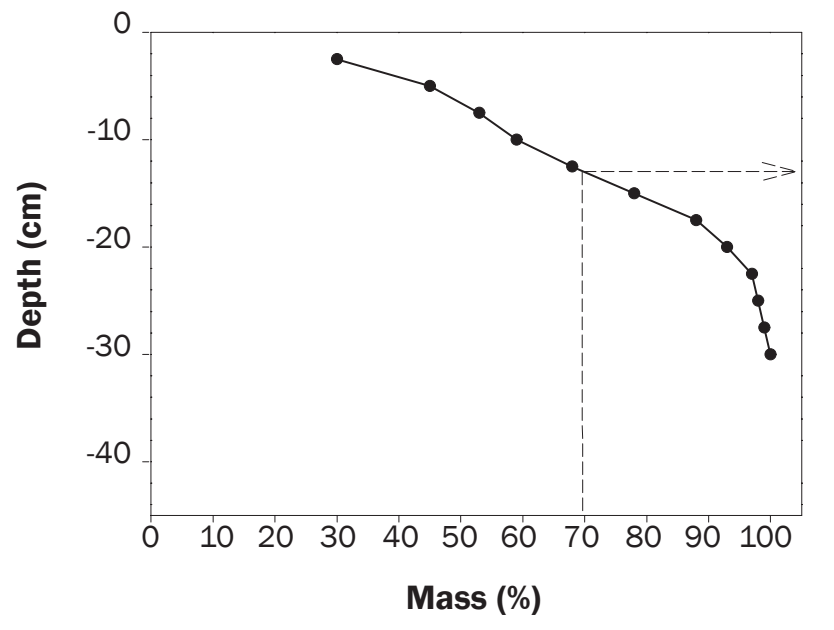

Hamblin, A., D. Tennant, and M. Perry. 1990. The cost of stress: Dry matter partitioning changes with seasonal supply of water and nitrogen to dryland wheat. Plant and Soil 122(1):47-58.

Izaurralde, R.C., N.G. Juma, W.B. McGill, D.S. Chanasyk, S. Pawluk, and M.J. Dudas. 1993. Performance of conventional and alternative cropping systems in cryoboreal subhumid central Alberta. The Journal of Agricultural Science 120(01):33-42.

Janzen, H.H., T. Entz, and B.H. Ellert. 2002. Correcting mathematically for soil adhering to root samples. Soil Biology and Biochemistry 34(12):1965-1968.

Jastrow, J., J. Amonette, and V. Bailey. 2007. Mechanisms controlling soil carbon turnover and their potential application for enhancing carbon sequestration. Climatic Change 80(1):5-23.

Johnson, D.R., and A.J. Makinson. 1988. Soil survey of Umatilla County area, Oregon. Washington, DC:
USDA Soil Conservation Service, US Government Printing Office.

Karow, R.S., B.L. Klepper, R.W. Rickman, and T.R. Toll. 1993. Early growth and development of cereals. Corvallis, OR: Oregon State University Extension Service.

Kätterer, T., A.-C. Hansson, and O. Andrén. 1993. Wheat root biomass and nitrogen dynamics - effects of daily irrigation and fertilization. Plant and Soil 151(1):21-30.

Krynine, P.D. 1937. Age of till on "Palouse soil" from Washington. American Journal of Science 33(195):205-216.

McCool, D.K., C.D. Pannkuk, A.C. Kennedy, and P.S. Fletcher. 2008. Effects of burn/low-till on erosion and soil quality. Soil and Tillage Research 101(1-2):2-9.

McCool, D.K., and D.R. Roe. 2005. Long-term erosion trends on cropland in the Pacific Northwest. Paper No. PNW05-1002. In 2005 Pacific Northwest Section Meeting American Society of Agricultural Engineers. Lethbridge, Alberta, Canada, 22-24 September.
McCool, D.K., K.E. Saxton, and P.K. Kalita. 2006. Winter runoff and erosion on northwestern USA cropland. Paper No. 062190. In 2006 Annual International Meeting American Society of Agricultural and Biological Engineers. Portland, Oregon, USA, 9-12 July. McCool, D.K., W.H. Wischmeier, and L.C. Johnson. 1982. Adapting the Universal Soil Loss Equation to Pacific Northwest. Transactions of the American Society of Agricultural Engineers 25(4):928-934.

McCool, D.K., J.F. Zuzel, J.D. Istok, G.E. Formanek, M. Molnau, K.E. Saxton, and L.F. Elliott. 1987. Erosion processes and prediction for the Pacific Northwest. In Proceedings of STEEP-Conservation Concepts and Acomplishments, ed. L.F. Elliott. Pullman, Washington, 20-21 May.

Miller, R., and J. Jastrow. 2000. Mycorrhizal fungi influence soil structure. In Arbuscular Mycorrhizas: Physiology and Function, eds. Y. Kapulnik and D.J. Douds. Dordrecht, Netherlands: Kluwer Academic Publishers. 
Paustian, K., O. Andren, M. Clarholm, A.C. Hansson, G. Johansson, J. Lagerlof, T. Lindberg, R. Pettersson, and B. Sohlenius. 1990. Carbon and nitrogen budgets of four agro-ecosystems with annual and perennial crops, with and without $\mathrm{N}$ fertilization. Journal of Applied Ecology 27(1):60-84.

Rasmussen, P.E., H.P. Collins, and R.W. Smiley. 1994. Long-term management effects on soil productivity and crop yield in semi-arid regions of eastern Oregon. In Station Bulletin 675. Corvallis, OR: Agricultural Experiment Station, Oregon State University.

Renard, K.G., G.R. Foster, G.A. Weesies, D.K. McCool, and D.C.Yoder. 1997. Predicting Soil Erosion by Water: A Guide to Conservation Planning with the Revised Universal Soil Loss Equation (RUSLE). Washington, DC: US Government Printing Office, USDA.

Renard, K.G., and J.R. Simanton. 1990. Application of RUSLE to rangelands. In ASCE Conference, Watershed Planning and Analysis in Action, Committee on Watershed Management/Irrigation \& Drainage Division. Durango, Colorado, 9-11 July.

Russell, E.W. 1961. Crop Conditions and Plant Growth. New York: John Wiley and Sons Ltd.

Schillinger, W.F. 2011. Rainfall impacts winter wheat seedling emergence from deep planting depths. Agronomy Journal 103(3):730-734.

Steele, R.G.D., and J.H. Torrie. 1960. Principles and Procedures of Statistics. New York: McGraw Hill.

USDA. 1978. Palouse cooperative river basin study. USDA Soil Conservation Service, USDA Forest Service, and USDA Economics, Statistics, and Cooperative Services Report 797-658.Washington DC: Government Printing Office.

USDA ARS (Agricultural Research Service). 1995. WEPP Model Documentation.USDA-Water Erosion Prediction Project, Hillslope Profile and Watershed Model Documentation, NSERL Report \#10, July 1995. http://www.ars.usda.gov/Research/docs. htm?docid $=18073$.

USDA ARS. 2008. Draft Science Documentation, Revised Universal Soil Loss Equation, Version 2. http://www. ars.usda.gov/sp2UserFiles/Place/64080510/RUSLE/ RUSLE2_Science_Doc.pdf.

USDA NASS (National Agricultural Statistics Service). 2012. Quick Stats. http://quickstats.nass.usda.gov/.

Williams, J.D. 2008. Soil erosion from dryland winter wheat-fallow in a long-term residue and nutrient management experiment in north-central Oregon. Journal of Soil and Water Conservation 63(2):53-59, doi:10.2489/jswc.63.2.53.

Williams, J.D., S. Dun, D.S. Robertson, J.Q. Wu, E.S. Brooks, D.C. Flanagan, and D.K. McCool. 2010. WEPP simulations of dryland cropping systems in small drainages of northeastern Oregon. Journal of Soil and Water Conservation 65(1):22-33, doi:10.2489/ jswc.65.1.22.
Williams, J.D., H.T. Gollany, M.C. Siemens, S.B. Wuest, and D.S. Long. 2009. Comparison of runoff, soil erosion, and winter wheat yields from no-till and inversion tillage production systems in northeastern Oregon. Journal of Soil and Water Conservation 64(1):43-52, doi:10.2489/ jswc.64.1.43.

Williams, J.D., D.E. Wilkins, C.L. Douglas, and R.W. Rickman. 2000. Mow-plow crop residue management influence on soil erosion in north-central Oregon. Soil and Tillage Research 55(1-2):71-78.

Zuzel, J.F., R.R. Allmaras, and R.N. Greenwalt. 1982. Runoff and soil erosion on frozen soils in northeastern Oregon. Journal of Soil and Water Conservation 37(6):351-354. 